\title{
Three Competing Models on Customer Loyalty in the Context of Mobile Subscribers
}

\author{
Mohammad Muzahid Akbar ${ }^{1}$ \\ ${ }^{1}$ School of Business, Independent University, Bangladesh \\ Correspondence: Mohammad Muzahid Akbar, Room \# 3006-E, School of Business, Plot-16, Block-B, \\ Aftabuddin Ahmed Road, Bashundhara R/A, Dhaka, Bangladesh.E-mail: zahid_89@yahoo.com
}

Received: March 25, 2013

Accepted: April 17, 2013 Online Published: May 27, 2013

doi:10.5539/ijms.v5n4p42

URL: http://dx.doi.org/10.5539/ijms.v5n4p42

\begin{abstract}
Three competing models based on same six constructs have been examined to find out which model explains mobile subscribers' loyalty most meaningfully. Data were collected from 195 subscribers of the state-owned (or public) mobile operator in Bangladesh. In all three models, the constructs were measured with same indicators and most of the causal paths were common too in all three models. Confirmatory Factor Analysis was employed to assess the validity and reliability of each construct and the results were satisfactory. Structural Equation Modeling was used to assess the data-model fit. All three models displayed satisfactory goodness-of-fit indices. Path analysis was used to assess the hypotheses. In first two models all hypotheses were empirically supported. However, eight out of nine hypotheses were supported in the third model. To evaluate the competing models, chi-square $(\chi 2)$ difference statistics and change in degrees of freedom $(d f)$ have been used. Later on, PNFI, ratio of explained paths, and explained variance $\left(\mathrm{R}^{2}\right)$ in endogenous variables were considered to identify the best customer (subscriber) loyalty model. By far the second model showed superior results. This study might encourage the mobile operators to take necessary measures to create a loyal customer base.
\end{abstract}

Keywords: service quality, trust, switching cost, customer satisfaction, corporate image, customer loyalty, structural equation modeling, competing models

\section{Introduction}

In last three decades, due to significant liberalization and privatization, the entire telecommunications industry has become a dynamic and growing service industry, which is subject to increasing competition (Graack, 1996). In recent years, in some Asian countries the number of mobile subscribers has exceeded the number of fixed-line subscribers (Fink, Matto, \& Rathindran, 2003). In Bangladesh the scenario is not much different as its socioeconomic profile has presented the industry a tremendous growth opportunity.

Currently six telecommunications companies or mobile operators (five private and one state-owned) are operating in Bangladesh. Due to aggressive competition, the incumbent mobile operators are forced to revisit their strategies to maintain/improve their competitive advantage(s). Interestingly, in Bangladesh mobile subscribers (especially, pre-paid subscribers) do not exhibit very strong loyalty to any particular mobile operator as they have the option of switching to another operator for more convenient and suitable service offerings (Akbar \& Parvez, 2009). Main reason of such behavior is the low switching costs of mobile services in Bangladesh. Hence, the mobile operators are pressed to undertake various strategic and tactical measures to attract new customers while retaining the existing ones. At this juncture, the mobile operators must identify and understand various antecedents of customer loyalty; since, customer loyalty ensures higher profit through enhanced revenues, reduced costs to acquire customers (Sharp \& Sharp, 1997).

As reported in the relevant literature, high quality service helps to generate customer satisfaction and loyalty, increase market share, and improve productivity and financial performance (Anderson, Fornell, \& Lehmann, 1994; Lewis, 1993). Corbitt, Thanasankit, and Yi (2003) found strong effect of trust on customer loyalty. Aydin and Ozer (2005) reported switching costs and corporate image exhibiting positive and direct impact on customer loyalty. Numerous researchers proved that customer satisfaction is a prerequisite of customer retention and loyalty (Anderson \& Sullivan, 1993). These commonly cited antecedents of customer loyalty are intended to be used to develop and assess three competing customer loyalty models in the context of a group of subscribers of the only public mobile operator in Bangladesh. 


\section{Literature Review}

\subsection{Service Quality}

Service quality refers to the consumer's overall impression of the relative inferiority or superiority of the services (Zeithaml, Parasuraman, \& Berry, 1990). Service quality is also conceptualized as the comparative evaluation between customer's expectation(s) regarding a service to be received and perception of the service being received (Dotchin \& Oakland, 1994; Parasuraman, Zeithaml, \& Berry, 1988).

In order to measure the quality of services Parasuraman et al. $(1985,1988)$ developed a scale called SERVQUAL, which identified five dimensions of service quality (viz. reliability, responsiveness, assurance, empathy, and tangibles) that link specific service characteristics to customer expectations. SERVQUAL was criticized due to the difficulties related to operationalization and measurement by researchers (Carman, 1990; Taylor, 1995).

Grönroos (1984) came up with two components such as technical quality ("what" is delivered) and functional quality ("how" is delivered) to assess service quality and these dimensions are typically moderated by the company image. Technical quality refers to what the service process leads to for the customer in a "technical" sense. Functional quality refers to 'how' a service is provided (which may include issues like-courtesy, attention, promptness, professionalism, and so on).

Cronin and Taylor (1992) introduced performance-based scale of service quality called SERVPERF, which relies on assessing service provider's performance to determine whether the service was delivered adequately and competently. Brady and Cronin (2001) advanced the hierarchical conceptualization of service quality and identified three dimensions: outcome quality (i.e. core services), interaction quality (i.e. service delivery process), and physical environment quality (i.e. tangible).

Irrespective of these diverse views related to service quality assessment, the customers tend to form a distinct overall evaluation of service quality, which eventually influences their behavioral intentions (Dabholkar, Shepherd, \& Thorpe, 2000).

\subsection{Trust}

Researchers had established that trust is essential for building and maintaining long-term relationships (Singh \& Sirdeshmukh, 2000). Moorman, Deshpande, and Zaltman (1993) defined trust as the willingness of an exchange partner to rely on the other party in whom the former party has confidence (Hadjikhani \& Thilenius, 2005). Trust refers to a party's reliance and positive expectations on/towards another party to achieve desired outcome(s) (Beatty, Mayer, Coleman, Reynolds, \& Lee, 1996). According to Sirdeshmukh, Singh, and Sabol (2002), trust is customer held expectations whether the service provider "can be relied on to deliver on its promises". Doney and Cannon (1997) referred to trust as the perceived credibility and benevolence of the exchange partner.

Anderson and Narus (1990) mentioned when a party believes that the actions of the other party will bring positive outcomes, trust can be developed. Doney and Cannon (1997) also said that the trusted party must have the ability to meet its obligations towards the other party and continue to do so in the future. Liang and Wang (2008) added that trusted party should be willing to make sacrifices to satisfy the customers' needs in the relationship. According to Lau and Lee (1999), trust engenders positive behavioral intentions between exchange partners. Sharma and Patterson (1999) also said that trust motivates the customers to continue their relationships with the service provider.

\subsection{Switching Costs}

According to Porter (1998), switching costs are the costs involved in changing from one service provider to another. Switching costs are identified as the factor(s) contributing to maintaining a relationship (Morgan \& Hunt, 1994). In addition to measurable monetary costs; switching costs also include time and psychological cost related to facing the uncertainty of finding a better alternative (Dick \& Basu, 1994; Kim, Kliger, \& Vale, 2003). Jackson (1985) defined that, switching costs are the sum of economic, psychological, and physical costs. In a nutshell, switching costs refer to the set of additional costs required to terminate the relationship with the current service provider and secure an alternative one. Burnham, Frels, and Mahajan (2003) identified eight facets of switching costs based on the evidences found from two continuous service industries. Aydin and Ozer (2005) conceptualized switching costs for mobile phone services by assimilating notions (i.e. perceived monetary costs, uncertainty costs, evaluation costs, learning costs, and set-up costs) borrowed from researchers like Burnham et al. (2003); and Jones, Beatty and Mothersbaugh (2002). 


\subsection{Corporate Image}

Barich and Kotler (1991) tried to define corporate image as the overall impression of a firm left in customer's mind. Corporate image is a perception regarding a firm held in customers' memory and works as a filter, which affects the perception of the operation/activities run by the firm (Lai, Griffin, \& Babin, 2009). A firm's various activities and attributes eventually settle in customers' minds, thus resulting in certain mental image(s) relatable to the firm intuitively (Nguyen \& Leblanc, 2001). Corporate image germinates as the customers actively or passively receive and process information about a firm from various sources.

Kennedy (1997) said that corporate image has two dimensions; functional (tangible characteristics) and emotional (feelings and attitude towards a firm). Nguyen and Leblanc (2001) said that as the customers get exposed to the realities created by a firm, they tend to construct an image regarding the firm. Generally, the customers keep an array of reflections embodied in mental or intellectual framework about a firm in their minds (Orth \& Green, 2009). Eventually corporate image influences customers' behavior or sometimes even their behavioral outcome(s) like-satisfaction, repurchase intention or recommending others about the firm or its products or services.

\subsection{Customer Satisfaction}

Satisfaction is commonly interpreted as a feeling, which results in from a process of evaluating what has been received against what was expected from the purchase and usage of a product or service (Armstrong \& Kotler, 1996). Bitner and Zeithaml (2003) stated that satisfaction is the customer's evaluation of a product or service in terms of whether that product or service has met his/her needs and expectations. According to Boselie, Hesselink, and Wiele (2002) satisfaction is a positive and affective state of mind resulting from the appraisal of all aspects of a party's working relationship with another. Previous studies have identified two aspects of customer satisfaction: transaction specific satisfaction and overall or cumulative satisfaction (Andreassen, 2000). According to Wang, Lo and Yang (2004) in the past studies, overall satisfaction has been used more than transaction specific satisfaction to predict customer behavior. This paper has also focused on overall satisfaction. Satisfied customers tend to be more loyal and they are less likely to move to other competitor(s) (Baldinger \& Rubinson, 1996).

\subsection{Customer Loyalty}

Pearson (1996) defined customer loyalty as the mindset of a customer who holds favorable attitude toward a company, commits to repurchase the company's product (or services), and recommends the product (or services) to others. In the relevant literature, customer loyalty is identified with two dimensions: attitudinal as well as behavioral. Customer's attitudinal component captures notions like: repurchase intention, willingness to recommend the company or its products to others, demonstrating resistance to switch to the competitors (Cronin \& Taylor, 1992; Prus \& Brandt, 1995), and even willingness to pay a price premium (Narayandas, 1996; Zeithaml, Berry, \& Parasuraman, 1996). The behavioral aspect represents: actual repeat purchase, positive word of mouth communication, and continuing preference for the same product or brand (Lee, Lee, \&, Feick, 2001). Although customer loyalty has been phrased differently (i.e. brand loyalty, vendor loyalty, service loyalty, store loyalty, and so on) considering its field specific purposes and relevance, it represents an important constituent for developing a lasting competitive advantage (Kotler \& Singh, 1981).

\subsection{Relationship between Service Quality and Customer Satisfaction}

In the recent past, there has been a heightened emphasis on service quality and customer satisfaction in business and academia alike. Cronin and Taylor (1992) proved service quality is an important antecedent of customer satisfaction. Sureshchandar, Rajendran, and Anantharaman, (2002) had also reported a strong relationship between service quality and customer satisfaction in their study. Spreng and Mackoy (1996) showed that higher service quality leads to higher customer satisfaction while working on the model developed by Oliver (1997). Studies focusing on telecommunication services carried out by Wang et al. (2004), and Turel and Serenko (2006) reaffirmed the positive relationship between service quality and customer satisfaction. Therefore, following hypothesis has been proposed:

Hypothesis 1: Perceived service quality has a positive effect on customer satisfaction.

\subsection{Relationship between Customer Satisfaction and Corporate Image}

Corporate image is an outcome of the process related to a customer's experience or encounter with company (MacInnis \& Price, 1987). In that process, intangible ideas, thoughts or feelings tend to get congregated in customer's mind that eventually germinate into perceived corporate image (Yuille \& Catchpole, 1977). If the customer's encounter with the company generates satisfactory results, it would definitely help forming a positive 
impression about the company. Anderson and Sullivan (1993) reported that satisfaction leads to reputation, which reflects the fact that satisfaction improves image (Andreassen \& Lindestad, 1998). Bontis, Booker, and Serenko (2007) studied the mediating impact of organizational (corporate) reputation on customer loyalty and service recommendation in banking sector. While addressing the consequence(s) of customer satisfaction the authors claimed that customer satisfaction boosts the reputation of the company considering the service environment. Hence, the researcher has hypothesized the following:

Hypothesis 2: Customer satisfaction has a positive effect on corporate Image.

\subsection{Relationship between Customer Satisfaction and Customer Loyalty}

Several authors (Bolton \& Drew, 1991; Fornell, 1992) reported a positive link between customer satisfaction and customer loyalty. Numerous studies in the service sector have also empirically validated the positive relationship between satisfaction and behavioral intentions such as customer retention and positive word of mouth (Anderson \& Sullivan, 1993; Bansal \& Taylor, 1999; Cronin \& Taylor, 1992). Hart and Johnson (1999) mentioned that one of the vital prerequisites of genuine customer loyalty is total satisfaction. Likewise, Vesel and Zabkar (2009) proved that customer satisfaction is one of the major precursors of customer loyalty. Hence, following hypothesis has been proposed:

Hypothesis 3: Customer satisfaction has a positive effect on customer loyalty.

\subsection{Relationship between Corporate Image and Customer Loyalty}

Nguyen and Leblanc (2001) proved that corporate image is positively linked with customer loyalty in three sectors namely, telecommunication, retailing and education. Kristensen, Martensen and Gronholdt (2000) had also reported the positive relationship between corporate image and customer loyalty in the context of Danish postal services. Andreassen and Lindestad (1998) also mentioned that corporate image plays a significant role in fostering customer loyalty. Hence, following hypothesis has been proposed:

Hypothesis 4: Corporate Image has a positive effect on customer loyalty.

\subsection{Relationship between Service Quality and Customer Loyalty}

Jones et al. (2002) identified positive relationships of service quality with repurchase intention, recommendations, and resistance to better alternatives. Rust and Zahorik (1993) investigated the positive relationship between perceived service quality and consumer loyalty in banking. Buzzell and Gale (1987) reported that high service quality generally results in repeated sales, which nourishes customer loyalty. Boulding, Kalra, Staelin, and Zeithaml (1993) pointed out that high (perceived) service quality eventually leads to high level of purchase intentions. Therefore, following hypothesis has been proposed:

Hypothesis 5: Perceived service quality has a positive effect on customer loyalty.

\subsection{Relationship between Trust and Customer Loyalty}

Many researchers had reported that trust is fundamental in developing customer loyalty (Moorman et al., 1993; Morgan \& Hunt, 1994; Singh \& Sirdeshmukh, 2000; Sirdeshmukh, Singh, \& Sabol, 2002). Chiou (2004) said that trust happens to be directly and positively related with customer satisfaction as well as customer loyalty. Likewise, Aydin and Ozer (2005) referred to trust as an important antecedent of customer loyalty while focusing on mobile phone services. Therefore, following hypothesis has been formulated:

Hypothesis 6: Trust has a positive effect on customer loyalty.

\subsection{Relationship between Switching Costs and Customer Loyalty}

The degree of switching costs may have a positive influence on customer loyalty in some industries (Dick \& Basu, 1994; Gremler \& Brown, 1996). Andreasen (1982) reported the positive effect of high switching costs on customer loyalty in relation to medical services. Lam, Shankar, and Murthy (2004) presented evidence that switching cost is positively related to customer loyalty. Therefore, following hypothesis has been formulated:

Hypothesis 7: Perceived switching cost has a positive effect on customer loyalty.

\subsection{Relationship between Service Quality and Trust}

Many studies have admitted the relationship between service quality and trust is a positive and formidable one in context of relationship marketing (Hsieh \& Hiang, 2004). High quality service may help the service provider(s) to gain the confidence of the customers (Doney \& Cannon, 1997). Foster and Cadogen (2000) established that perceived service quality positively effects customer trust, so did Coulter and Coulter (2003). Therefore, following hypothesis has been proposed: 
Hypothesis 8: Perceived service quality has a positive effect on trust.

\subsection{Relationship between Corporate Image and Trust}

In the marketing literature, reputation or image of a firm is often linked with its credibility and trustworthiness as perceived by the customers (Herbig \& Milewicz, 1993; Hyde \& Gosschalk, 2005). Numerous researchers have tried to explain the connection between reputation and corporate image with consumers' trust; especially in the context of online businesses (Jarvenpaa, Tractinsky \& Vitale, 2000; Walczuch, Seelen, \& Lundgren, 2001). Lin and $\mathrm{Lu}(2010)$ presented evidence in their study that corporate image has strong positive impact on trust. The researcher has hypothesized the following:

Hypothesis 9: Corporate Image has a positive effect on trust.

\subsection{Relationship between Corporate Image and Customer Satisfaction}

According to Grönroos (1990) "(corporate) image is a filter which influences the perception of the operation of the company". He also said that a favorable image of a firm should be considered an asset and it may influence customers' perception of quality and satisfaction. If the customers are satisfied, their attitude toward the company is improved and eventually this improved attitude or impression will influence consumers' satisfaction (Andreassen \& Lindestad, 1998). Many researchers established that corporate image has a significant contributory role on developing customer satisfaction (Bolton \& Drew, 1991; Fornell, 1992). Hence, the following hypothesis has been proposed:

Hypothesis 10: Corporate Image has a positive effect on customer satisfaction.

\section{Conceptual Framework}

Based on the literature review three competing models (Figure 1 and Figure 2) on customer loyalty have been developed. Model 1 has there are three exogenous variables and three endogenous variables. Model 2 has two exogenous variables and four endogenous variables. Model 3 has three exogenous variables and three endogenous. The hypotheses and the number of hypotheses in respective model(s) are shown in Figure 1 and Figure 2. Considering the issue of same constructs and same indicators employed in all three models, these models can be called nested models (Hair, Anderson, Tatham, \& Black, 2006). However, main objective of this study is evaluating these competing models.

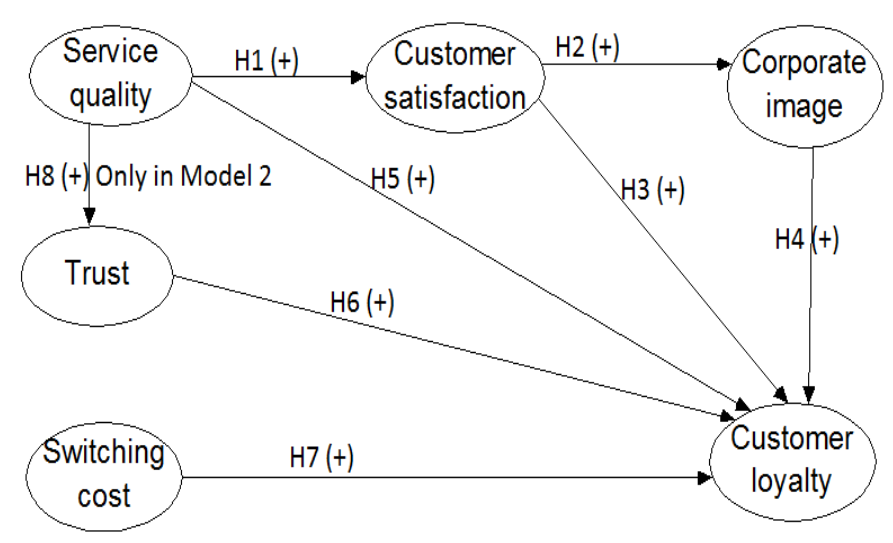

Figure 1. Model 1 (7 hypotheses) and model 2 (8 hypotheses) 


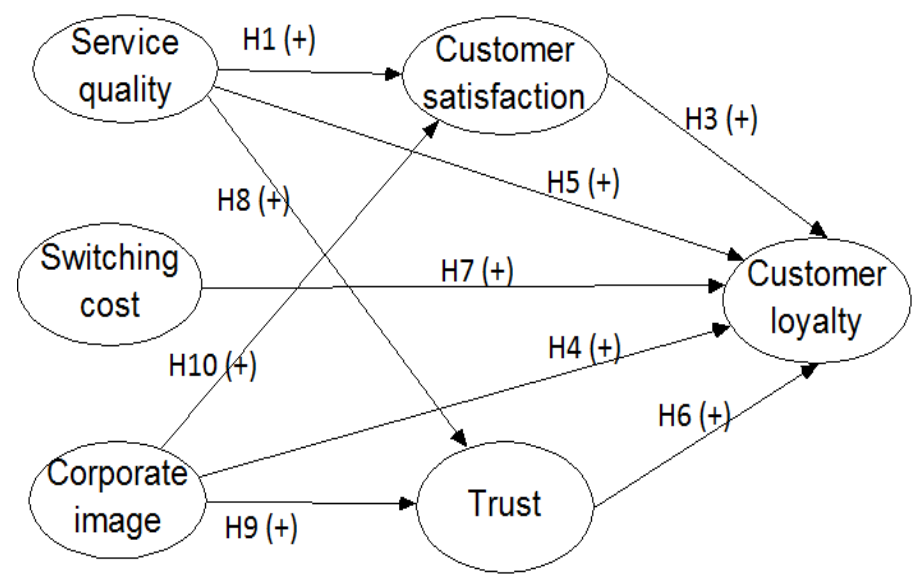

Figure 2. Model 3 (9 hypotheses)

\section{Methodology}

\subsection{Sampling and Data Collection}

The author used quota sampling and total 300 questionnaires were distributed among the subscribers of the public mobile operator in Bangladesh. Only those subscribers were considered for data collection who had been receiving the services of that operator for at least one year. These respondents were chosen from Dhaka metropolitan area. The mode of participation was voluntary. Data collection technique was survey via personal interviews. Initially, usable sample size was 201. After removing six outliers, the final number of usable questionnaires was 195 . Thus, the successful response rate was $40.25 \%$. The average age of the respondents was 29.6 years. $67 \%$ respondents were male and $33 \%$ were female.

\subsection{Measures}

A structured questionnaire was used to collect data, which was comprised of six scales borrowed from earlier researchers. Like the earlier researchers, the author has used 5 point likert scale. Perceived service quality (six-item scale) has been measured by employing a unidimensional scale covering all the base services (i.e. coverage of calling area, value-added services, customer support services, suppliers' services of the operator, and services in campaigns) germane to mobile services as identified by Aydin and Ozer (2005). This scale's reported reliability is 0.827 .

Trust (five-item scale) has been measured by using several complementary definitions as mentioned in the study of Aydin and Ozer (2005) and this scale has a reported reliability of 0.856. Customer satisfaction was measured by using four items adopted from Cronin, Brady and Hult (2000) and Wang et al. (2004), and the reported reliability of this scale is above 0.886 . Switching costs were measured by five items adapted from Ping (1993), which has a reported reliability of 0.938 . Corporate image was measured by using five items borrowed from Bayol, LaFoye, Tellier, and Tenenhaus (2001) and its reliability is 0.871 . To measure customer loyalty five-item scale developed by Narayandas (1996) was used, and the reported reliability of this scale is 0.824 .

\subsection{Data Analysis}

The researcher has employed both descriptive and inferential statistics. For that purpose, SPSS 18 was used. Confirmatory factor analysis (CFA) and Structural equation modeling (SEM) were carried out by using AMOS 20.

\section{Results}

\subsection{Descriptive Statistics}

Descriptive statistics and the reliability coefficients of the studied variables are presented in Table 1. Cronbach alphas for all the constructs found to be above the standard set by Nunnally (1978), which is 0.70 . Although mean values of the constructs seem to be fairly high, in isolation these descriptive statistics do not mean much. Hence, other statistics must be consulted. 
Table 1 . Descriptive statistics and reliability coefficients $(n=195)$

\begin{tabular}{lllll}
\hline Scales & Number of items & Alpha & M & SD \\
\hline Service quality (SQ) & 6 & 0.89 & 4.53 & 0.49 \\
Trust (TR) & 5 & 0.86 & 4.36 & 0.60 \\
Switching cost (SC) & 5 & 0.85 & 4.07 & 0.45 \\
Corporate image (CI) & 5 & 0.91 & 4.29 & 0.45 \\
Customer satisfaction (CS) & 4 & 0.84 & 4.61 & 0.43 \\
Customer loyalty (CL) & 5 & 0.87 & 4.11 & 0.39 \\
\hline
\end{tabular}

\subsection{Testing Multivariate Assumptions}

Data screening was carried out to test the multivariate assumptions (normality, homoscedasticity, linearity, and multicollinearity), because any violation of these assumptions usually undermines the use of multivariate statistical techniques (Hair et al., 2006). According to Kline (2005), testing multivariate normality is often difficult. Hence, as a 'quick and dirty' method sometimes researchers test univariate normality of each observed variable and if these variables found to be normally distributed, it is assumed that multivariate normality exists (Garson, 2012). Skewness (ranging from 0.682 to 0.755 ) and kurtosis (ranging from -0.146 to 0.907 ) values found for the observed variables were within the acceptable range \pm 2 (Garson, 2012). Later on, histograms of the observed variables were visually inspected and the histograms had very close resemblance with an ideal histogram drawn from a normally distributed dataset (Hair et al., 2006).

Homoscedasticity was tested using scatterplots of residuals. The assumption regarding randomness of residuals supposed to be met if scatterplots show no definite pattern(s). As per author's visual inspection, the scatterplots did not show any definite pattern(s), so the condition of homoscedasticity was met. Linearity was assessed by running series of simple linear regression analysis and by examining the residuals using Normal Probability P-P Plots (Hair et al., 2006). As the points were almost in a straight line around the diagonal axis, no violation of linearity assumption can be reported. To detect multicollinearity, Variance inflation factor (VIF) and tolerance values for all the constructs were checked. VIF values (ranging from 1.464-3.135) were less than 10.0, and tolerance values (ranging from $0.319-0.683$ ) were greater than 0.10 but less than 1.0 . These VIF and tolerance values suggest absence of multicollinearity (Kline, 2005).

\subsection{Confirmatory Factor Analysis (CFA) and Data Cleaning}

Scale reliability and validity were assessed using confirmatory factor analysis (Anderson \& Gerbing, 1988).The Measurement Model had six (6) latent constructs and each construct had several indicators/items pertinent to its scale. Initially, the first-order CFA model (with all 30 items) was drawn to assess the goodness-of-fit indices of the model (Table 2). Other than the $\chi^{2} / \mathrm{df}(2.02)$, CFI (0.907), and RMSEA (0.072) values, the initial measurement model (CFA1) did not yield a perfect fit for the data. Hence, the measurement model was examined by checking standardized factor loadings, standardized residuals, and modification indices (MI) as suggested by (Hair et al., 2006). In that process, item no. 9 with very low factor loading (i.e. 0.197) was considered for elimination, since standardized factor loading greater than 0.50 is considered acceptable (Bollen, 1990).

Table 2. Goodness-of-fit results for measurement models

\begin{tabular}{lllllllll}
\hline Model & $\chi^{2}$ & df & $\chi^{2}$ df & P & GFI & TLI & CFI & RMSEA \\
\hline CFA1 Model (with 30 items) & 786.0 & 390 & 2.02 & 0.0001 & 0.879 & 0.887 & 0.907 & 0.072 \\
Revised CFA Model (with 29 items) & 722.8 & 362 & 2.00 & 0.0001 & 0.906 & 0.915 & 0.937 & 0.071 \\
\hline
\end{tabular}

In order to improve the model fit to the data, data were checked for outliers. To identify multivariate outliers, squared Mahalanobis distance ( $\left.\mathrm{D}^{2}\right)$ values were examined from AMOS output. Six (6) out of 201 cases had such high $\mathrm{D}^{2}$ values those were distinctly standing apart from other values. Thus, the evidence of multivariate outliers was found (Byrne, 2001). After removing those outliers the revised CFA model (with 29 items) produced a very satisfactory data-model fit (Table 2).

\subsubsection{Convergent Validity}

Convergent validity refers to how well the observed indicators relate to the unobserved construct(s) (Kline, 2005). Table 3 shows that each factor loading of the indicator was statistically significant at 0.001 level and no 
factor loading was less than the recommended level of 0.50 (Anderson \& Gerbing, 1988). The squared multiple correlations (i.e. item reliabilities) were also higher than the acceptable level of 0.50 (Bollen, 1990). According to Fornell and Larcker (1981) AVE value should be larger than 0.50 to indicate an acceptable level of convergent validity for a construct. The construct reliability should be greater than 0.70 (Nunnally, 1978). Table 3 presents satisfactory results regarding convergent validity and construct reliability for each construct.

Table 3. Measures to assess convergent validity of constructs from measurement model

\begin{tabular}{llllllll}
\hline Construct & Items & $\begin{array}{l}\text { Factor } \\
\text { Loading }(a)\end{array}$ & $\begin{array}{l}\text { Standard Error } \\
(b)\end{array}$ & $\begin{array}{l}\text { Critical } \\
\text { Ratio }(c)\end{array}$ & $\begin{array}{l}\text { Item } \\
\text { Reliability }\end{array}$ & $\begin{array}{l}\text { AVE } \\
(e)\end{array}$ & $\begin{array}{l}\text { Construct } \\
\text { Reliability }(f)\end{array}$ \\
\hline SQ & item1 & 0.718 & - & $(d)$ - & 0.516 & & \\
& item2 & 0.721 & 0.286 & 6.087 & 0.520 & & \\
& item3 & 0.798 & 0.328 & 6.191 & 0.637 & & \\
& item4 & 0.714 & 0.063 & 15.192 & 0.510 & & \\
& item5 & 0.726 & 0.138 & 8.291 & 0.527 & 0.551 & 0.880 \\
TR & item6 & 0.771 & 0.057 & 18.397 & 0.594 & & \\
& item7 & 0.774 & & & 0.599 & & \\
& item8 & 0.781 & 0.079 & 10.558 & 0.610 & & \\
& item10 & 0.769 & 0.098 & 9.855 & 0.591 & & \\
SC & item11 & 0.741 & 0.099 & 12.335 & 0.549 & 0.587 & 0.851 \\
& item12 & 0.734 & & & 0.539 & & \\
& item13 & 0.756 & & 0.112 & 0.572 & & \\
& item14 & 0.758 & 0.350 & 6.099 & 0.575 & & \\
& item15 & 0.770 & 0.136 & 8.119 & 0.593 & & \\
CS & item16 & 0.761 & 0.099 & 11.339 & 0.579 & 0.571 & 0.870 \\
& item17 & 0.795 & 0.112 & 9.313 & 0.632 & & \\
& item18 & 0.747 & & & 0.558 & & \\
& item19 & 0.817 & 0.230 & 6.468 & 0.667 & & \\
CI & item20 & 0.746 & 0.161 & 6.437 & 0.557 & 0.604 & 0.859 \\
& item21 & 0.862 & 0.099 & 12.335 & 0.743 & & \\
& item22 & 0.835 & & & 0.697 & & \\
& item23 & 0.720 & 0.180 & 6.209 & 0.518 & & \\
& item24 & 0.778 & 0.079 & 11.447 & 0.605 & & \\
& item25 & 0.729 & 0.091 & 9.387 & 0.531 & 0.619 & 0.890 \\
& item26 & 0.735 & & & 0.540 & & \\
& item27 & 0.719 & 0.152 & 6.557 & 0.517 & & \\
& item28 & 0.712 & 0.084 & 12.261 & 0.507 & & \\
& item29 & 0.757 & 0.180 & 6.209 & 0.573 & & \\
& item30 & 0.807 & 0.230 & 6.468 & 0.651 & 0.558 & 0.863 \\
& Alt & & & & & \\
& & & & & & \\
\end{tabular}

Note: (a) All item loadings in CFA model were significant at 0.001 level.

(b) S.E. stands for standard error of the covariance;

(c) C.R. is the critical ratio obtained by dividing the estimate of the covariance by its standard error. A value of C.R exceeding 1.96 represents significance level of 0.05 ;

(d) Some critical ratios were not calculated because loading was set to 1 to fix construct variance;

(e) Variance Extracted $(\mathrm{VE})=(\Sigma$ standardized loadings $2 / \Sigma$ standardized loadings $2+\Sigma \varepsilon j)$ (where $\varepsilon=$ error variance and $\Sigma$ is summation).

(f) Construct reliability $=$ (square of the summation of the factor loadings) $/$ \{(square of the summation of the factor loadings) + (square of the summation of the error variances) $\}$

\subsubsection{Discriminant Validity}

The most common method examining discriminant validity is whether AVE value of each construct exceeds the squared inter-construct correlations related to that construct (Fornell \& Larcker, 1981). In other words, the 
square root of AVE value of each construct should be more than its correlations with other constructs. Table 4 shows that the constructs have adequate level of discriminant validity.

Table 4. Square root values of AVE and inter-construct correlations

\begin{tabular}{lllllll}
\hline Constructs & SQ & TR & SC & CS & CI & CL \\
\hline SQ & 0.742 & & & & & \\
TR & $0.447^{* * *}$ & 0.766 & & & & \\
SC & $0.358^{* *}$ & $0.383^{* * *}$ & 0.756 & & & \\
CS & $0.527^{* * *}$ & $0.585^{* * *}$ & $0.325^{* *}$ & 0.777 & & \\
CI & $0.349^{* * *}$ & $0.345^{* * *}$ & $0.265^{* *}$ & $0.639^{* * *}$ & 0.787 & \\
CL & $0.444^{* * *}$ & $0.432^{* * *}$ & $0.117^{* *}$ & $0.453^{* * *}$ & $0.672^{* * *}$ & 0.747 \\
\hline
\end{tabular}

Note: Square root values of AVE (italic) are shown on the diagonal while the other entries represent inter-construct correlations. ${ }^{*} \mathrm{p}<.05,{ }^{* *} \mathrm{p}<.01,{ }^{* * *} \mathrm{p}<.001$.

\subsection{Structural Equation Modeling (SEM)}

Three structural models were drawn to examine the causal links by employing SEM under maximum likelihood method. As suggested in the literature (Bollen \& Long, 1993; Joreskog \& Sorbom, 1993; Kline, 1998) model fit should be assessed by employing several indices. Table 5 shows that the goodness-of-fit indices of each model have met the acceptable cut-off values and all three models yielded an adequate data-model fit.

Table 5. Goodness-of-fit indices of structural models

\begin{tabular}{lllll}
\hline $\begin{array}{l}\text { Goodness-of-fit } \\
\text { Indices }\end{array}$ & $\begin{array}{l}\text { Acceptable Cut-off } \\
\text { Values }\end{array}$ & Model 1 & Model 2 & Model 3 \\
\hline$\chi^{2}$ & & 857.8 & 865.4 & 854.9 \\
$d f$ & & 367 & 368 & 365 \\
$\chi^{2} / d f$ & $<3$ & 2.337 & 2.352 & 2.342 \\
GFI & $>0.90$ & 0.921 & 0.927 & 0.926 \\
CFI & $>0.90$ & 0.948 & 0.951 & 0.953 \\
RMSEA & $\leq 0.08$ & 0.071 & 0.070 & 0.070 \\
\hline
\end{tabular}

\subsection{Path Analysis and Hypotheses Testing}

Relevant measures of the causal paths portrayed in the structural models (standardized path coefficients $(\beta)$, standard errors, $p$ values, and hypotheses results) are displayed in Table 6. Considering the $p$ values in first two models, all hypotheses were empirically supported. But in third model, eight out of nine hypotheses were supported.

Table 6. Results of hypotheses testing

\begin{tabular}{lllllll}
\hline Model 1 & & & & & & \\
\hline Paths & $\begin{array}{l}\text { Hypothesized } \\
\text { Direction }\end{array}$ & $\beta$ & SE & Critical ratio & $p$ & Supported \\
\hline H1: SQ $\rightarrow$ CS & + & 0.349 & 0.083 & 3.851 & $* * *$ & Yes \\
H2: CS $\rightarrow$ CI & + & 0.676 & 0.108 & 7.128 & $* * *$ & Yes \\
H3: CS $\rightarrow$ CL & + & 0.523 & 0.102 & 5.928 & $* * *$ & Yes \\
H4: CI $\rightarrow$ CL & + & 0.371 & 0.097 & 3.721 & $* * *$ & Yes \\
H5: SQ $\rightarrow$ CL & + & 0.240 & 0.081 & 3.012 & 0.003 & Yes \\
H6: TR $\rightarrow$ CL & + & 0.231 & 0.075 & 2.955 & 0.003 & Yes \\
H7: SC $\rightarrow$ CL & + & 0.226 & 0.091 & 2.694 & 0.007 & Yes \\
\hline
\end{tabular}

Note: $\beta=$ standardized beta coefficients; S.E. $=$ standard error; C.R. $=$ critical ratio; ${ }^{*} \mathrm{p}<0.05$ 


\begin{tabular}{lllllll}
\hline Model 2 & & & & & & \\
\hline Paths & $\begin{array}{l}\text { Hypothesized } \\
\text { Direction }\end{array}$ & $\beta$ & SE & Critical ratio & $p$ & Supported \\
& + & 0.310 & 0.083 & 3.395 & $* * *$ & Yes \\
\hline H1: SQ -> CS & + & 0.680 & 0.108 & 7.142 & $* * *$ & Yes \\
H2: CS -> CI & + & 0.508 & 0.101 & 5.030 & $* * *$ & Yes \\
H3: CS -> CL & + & 0.368 & 0.097 & 3.694 & $* * *$ & Yes \\
H4: CI - CL & + & 0.235 & 0.083 & 2.847 & 0.004 & Yes \\
H5: SQ - C CL & + & 0.230 & 0.077 & 2.880 & 0.004 & Yes \\
H6: TR - CL & + & 0.224 & 0.091 & 2.678 & 0.007 & Yes \\
H7: SC $\rightarrow$ CL & + & 0.301 & 0.086 & 3.651 & $* * *$ & Yes \\
H8: SQ $\rightarrow$ TR & + & &
\end{tabular}

Note: $\beta=$ standardized beta coefficients; S.E. $=$ standard error; C.R. $=$ critical ratio; ${ }^{*} \mathrm{p}<0.05$

\begin{tabular}{lllllll}
\hline Model 3 & & & & & Supported \\
\hline Paths & $\begin{array}{l}\text { Hypothesized } \\
\text { Direction }\end{array}$ & $\beta$ & SE & $\begin{array}{l}\text { Critical } \\
\text { ratio }\end{array}$ & $p$ & \\
\hline H1: SQ -> CS & + & 0.260 & 0.073 & 3.196 & 0.001 & Yes \\
H3: CS -> CL & + & 0.533 & 0.107 & 4.981 & $* * *$ & Yes \\
H4: CI - C C & + & 0.382 & 0.099 & 3.777 & $* * *$ & Yes \\
H5: SQ -> CL & + & 0.241 & 0.086 & 2.814 & 0.005 & Yes \\
H6: TR -> CL & + & 0.228 & 0.076 & 2.900 & 0.004 & Yes \\
H7: SC - C CL & + & 0.229 & 0.092 & 2.731 & 0.006 & Yes \\
H8: SQ - > TR & + & 0.319 & 0.088 & 3.779 & $* * *$ & Yes \\
H9: CI -> TR & + & 0.140 & 0.107 & 1.319 & 0.187 & No \\
H10: CI -> CS & + & 0.579 & 0.079 & 6.453 & $* * *$ & Yes \\
\hline
\end{tabular}

Note: $\beta=$ standardized beta coefficients; S.E. $=$ standard error; C.R. $=$ critical ratio; ${ }^{*} \mathrm{p}<0.05$

The square multiple correlation $\left(\mathrm{R}^{2}\right)$ for the structural equation(s) index represents the percentage of variance in each endogenous variable (in its respective model) explained by the exogenous variable(s) as portrayed in the respective model. Interpretation of $\mathrm{R}^{2}$ is quite similar in other instances for each model (Figure 3, 4, and 5).The newly added path (from service quality to trust) in Model 2 has proven to be a significant. In Model 3, one out of two newly added paths has proven to be a significant, which is corporate image to customer satisfaction. However, whether the new path(s) has/have improved the model(s) will be discussed later on.

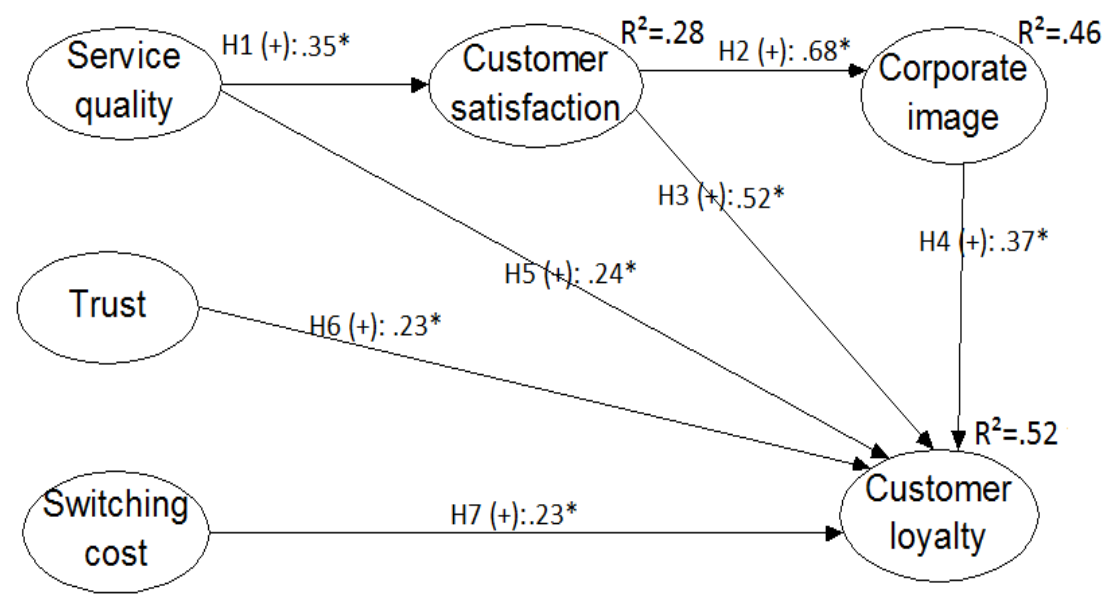

Figure 3. Structural model 1 with path coefficients 


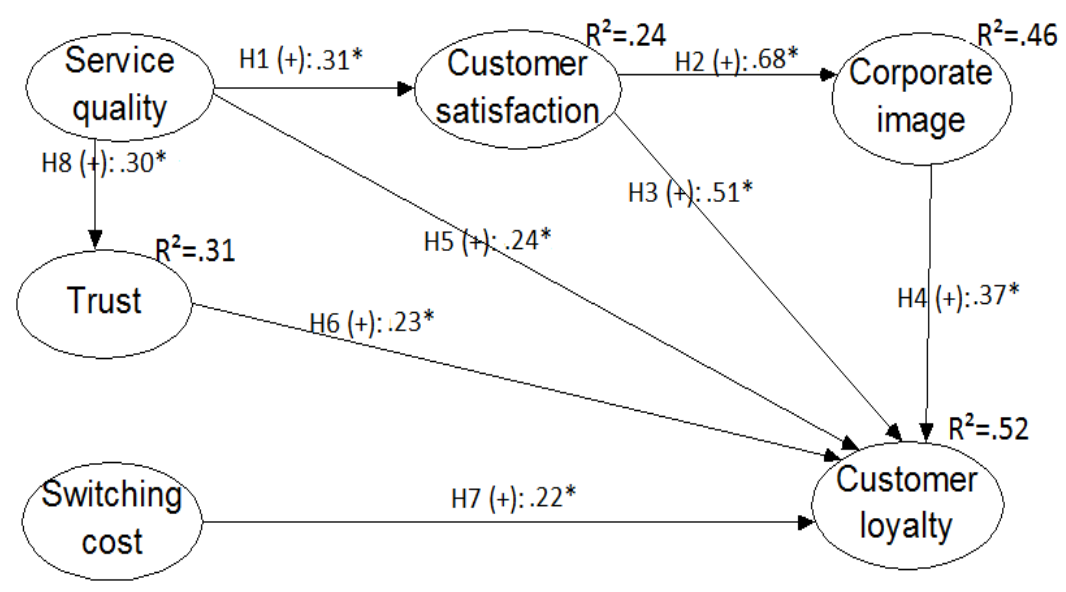

Figure 4. Structural model 2 with path coefficients

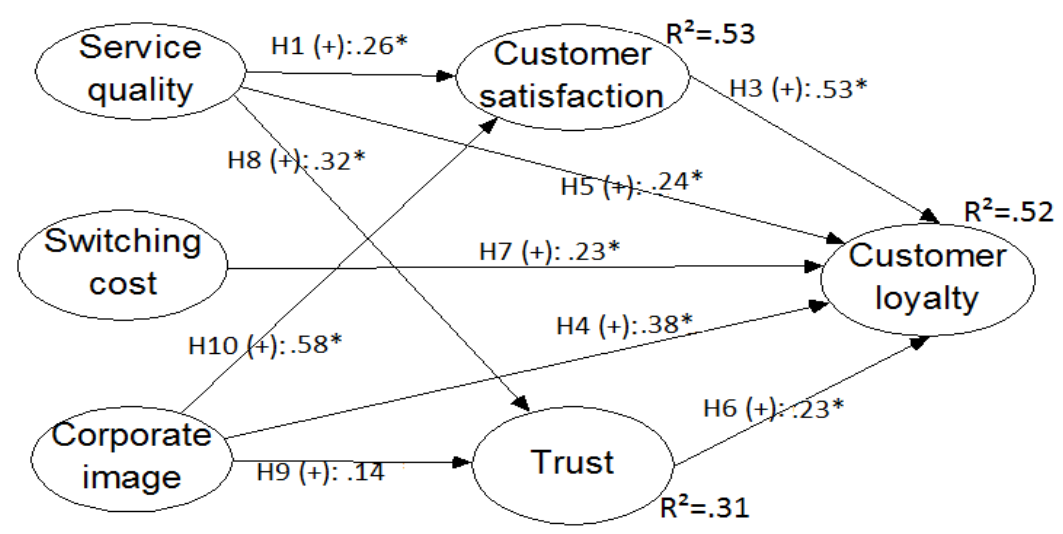

Figure 5. Structural model 3 with path coefficients

\subsection{Comparison of the Competing Models}

Generally, $\chi^{2}$ difference statistics is used to compare the relative fit of competing models in order to verify the competency of the respective models (Anderson \& Gerbing, 1988). Anderson and Gerbing (1988) said that the $\chi^{2}$ differences can be examined for statistical significance with the appropriate degrees of freedom $(d f)$ calculated from the difference in the number of estimated coefficients found between two competing models. For instance, Model A and Model B have same constructs (measured by the same indicators) and they are posited in the same way (most of the hypothesized causal paths are common) in both models. At the beginning both models had same (or common) causal paths; now for each additional path that is added or estimated in Model B, 1 less degree of freedom (than the degrees of freedom found in Model A) will be found and new $\chi^{2}$ value will be found (or re-estimated) for Model B. Now the statistical significance can be assessed for the $\Delta \chi^{2}$ value considering the change in degrees of freedom $\Delta \mathrm{df}$ ) in Model B. Specifically, for a model with one degree of freedom difference $(\Delta \mathrm{df}=1)$, a $\Delta \chi^{2}$ of 3.84 or greater would be significant at the 0.05 level (Hair et al., 2006). Table 7 presents a comparison among the competing (nested) models based on chi-square $\left(\chi^{2}\right)$ difference statistics. 
Table 7. Comparison of competing models (based on $\chi 2$ difference statistics)

\begin{tabular}{lllllll}
\hline Competing Models & $\begin{array}{l}\chi^{2} \text { (lower the } \\
\text { better) }\end{array}$ & $d f$ & $\Delta \chi^{2}$ & $\Delta$ df & $\begin{array}{l}\text { Critical value } \\
\text { at given df at } \\
0.95\end{array}$ & $\begin{array}{l}\text { Is } \Delta \chi^{2}> \\
\text { Critical } \\
\text { value? }\end{array}$ \\
\hline Model 1 & 858 & 367 & & & & \\
Model 2 & 865 & 368 & & & & \\
Model 3 & 855 & 365 & & & 3.84 & Yes \\
M1 vs. M2 & & & 7.60 & 1 & 5.99 & No \\
M1 vs. M3 & & 2.90 & 2 & 7.82 & Yes \\
M2 vs. M3 & & 10.50 & 3 & & \\
\hline
\end{tabular}

In Model 1 and Model 2, same constructs are posited in the same way; the differentiating features in Model 2 are: one more endogenous variable and one additional path. It is well known that $\chi 2$ value calculation gets influenced by the number of endogenous variables as well as the number of hypothesized paths (besides other factors). Considering the $\chi 2$ difference statistics, Model 2 shows better fit over Model 1. But comparison of Model 3 over Model 1 does not show noteworthy improvement. However, when Model 3 (three endogenous variables and nine paths) is compared with Model2 (four endogenous variables and eight paths), it shows significant and better fit over Model 2.

However, given the sensitivity of $\chi^{2}$ statistics due to sample size (Gerbing \& Anderson, 1993; James, Mulaik, \& Brett, 1982), additional fit indices can be consulted to compare competing models. Four criteria developed by Morgan and Hunt (1994) cited in Yen and Gwinner (2003) can also be considered to compare the competing models. Four criteria are: a) overall model fit as measured by CFI, b) percentage of the proposed significance paths, c) amounts of variance explained by $\mathrm{R}^{2}$, and d) parsimony, assessed by the parsimonious normed fit index (PNFI).

Table 8. Comparison of Competing Models (Based on Four Criteria)

\begin{tabular}{lllll}
\hline Fit Indices \& Criteria & $\begin{array}{l}\text { Acceptable Cut-off } \\
\text { Values }\end{array}$ & Model 1 & Model 2 & Model 3 \\
& $>0.90$ & 0.948 & 0.951 & 0.953 \\
CFI & $>0.50$; Higher value & 0.787 & 0.789 & 0.776 \\
PNFI & better fit & 7 out of 7 & 8 out of 8 & 8 out of 9 \\
Ratio of explained paths & & $(100 \%)$ & $(100 \%)$ & $(89 \%)$ \\
& & $\mathrm{CS}=.28$, & $\mathrm{CS}=.24$, & $\mathrm{CS}=.53$, \\
Explained variance $\left(\mathrm{R}^{2}\right)$ in & & $\mathrm{CI}=.46$, & $\mathrm{CI}=.46$, & $\mathrm{TR}=.31$, \\
Endogenous Variables & $\mathrm{CL}=.52$ & $\mathrm{TR}=.31$, & $\mathrm{CL}=.52$ \\
& & $\mathrm{CL}=.52$ & \\
\hline
\end{tabular}

As per Table 8 considering the CFI values and amounts of variance explained by $\mathrm{R}^{2}$ in endogenous variable(s), which model has the best fit can not be said conclusively or confidently. However, considering the PNFI values and the ratio of explained paths, Model 2 seems to be the best, and Model 1 appears to be the second best. However, the most important thing to remember is that the goodness-of-fit indices showed that all three models yielded a satisfactory fit for the data (Table 5).

\section{Discussion}

The present study is noteworthy for one reason. As to the knowledge of the author, in Bangladesh no other author(s) has/have done any study to understand mobile subscribers' loyalty using multiple competing models. In general, the results supported all hypothesized relationships (except the effect of corporate image on trust) with adequate statistical significance. Relationship between customer satisfaction and corporate image (or vice versa) seems to be the strongest and statistically significant one in all three models. Consistently impact of customer satisfaction on customer loyalty was strong and significant in all three models. Likewise, the impact of corporate image on customer loyalty was strong and significant. Impact of service quality on trust found to be another significant one. Such relational emphasis might help the mobile operators to identify important causal 
links in the subscriber loyalty model(s) and give due consideration to the right antecedents of subscriber loyalty. Hence, the mobile operators should identify the needful to create a loyal customer base.

The findings of this study have to be interpreted in the light of few limitations. First, data were collected only from the subscribers of one mobile operator; so the results can not be generalized to the entire industry. As data collection was limited to the Dhaka metropolitan area; so the findings can not be generalized for all subscribers that operator has throughout the country. Second, the current study was cross-sectional in nature, but to draw causal inferences more assertively and safely a longitudinal study would have been more appropriate (Poon, 2004). Third, while doing path analysis the direct and indirect effects or impact of exogenous and mediating variables on the endogenous variable were not estimated (considering the fact that the length of the paper is somewhat overwhelming as it is). Finally, inclusion of other variables like price perception, customer value etc. or both types of loyalty (attitudinal and behavioral, which would make the models non-nested) could have made the models robust and more interesting. In future research the author intends to conduct such a study.

\section{References}

Akbar, M. M., \& Parvez, N. (2009). Impact of service quality, trust \& customer satisfaction on customer loyalty. ABAC Journal, 29(1), 24-38.

Anderson, E. W., Fornell, C., \& Lehmann, D. R. (1994). Customer Satisfaction, Market Share, and Profitability: Findings from Sweden. Journal of Marketing, 58(4), 53-66.

Anderson, E., \& Sullivan, M. (1993). The antecedents and consequences of customer satisfaction for firms. Marketing Science, 12(1), 125-143. http://dx.doi.org/10.1287/mksc.12.2.125

Anderson, J. C., \& Gerbing, D. W. (1988). Structural equation modeling in practice: A review and recommended two step approach. Psychological Bulletin, 103, 411-423. http://dx.doi.org/10.1037/0033-2909.103.3.411

Anderson, J. C., \& Narus, J. A. (1990). A model of distributor firm and manufacturer firm working partnerships. Journal of Marketing, 54(January), 42-58.

Andreasen, A. R. (1982). Consumer satisfaction in loose monopolies: the case of medical care. Journal of Public Policy and Marketing, 2, 122-35.

Andreassen, T. W. (2000). Antecedents to satisfaction with service recovery. European Journal of Marketing, $34(1 / 2), 156-75$.

Andreassen, T. W., \& Lindestad, B. (1998). The Impact of Corporate Image in the Formation of Customer Loyalty. Journal of Service Research, 1(1), 82-92. http://dx.doi.org/10.1177/109467059800100107

Armstrong, G., \& Kotler, P. (1996). Principles of Marketing (7th ed.). India: Prentice Hall.

Aydin, S., \& Ozer, G. (2005). The analysis of antecedents of customer loyalty in the Turkish mobile telecommunication market. European Journal of Marketing, 39(7/8), 910-925. http://dx.doi.org/10.1108/03090560510601833

Baldinger, A. L., \& Rubinson, J. (1996). Brand loyalty: the link between attitude and behavior. Journal of Advertising Research, 36(6), 22-34.

Bansal, H. S., \& Taylor, S. F. (1999). The service provider switching model (SPSM): a model of consumer switching behavior in the service industry. Journal of service Research, 2(2), 200- 218.

Barich, H., \& Kotler, P. (1991). A framework for marketing image management. Sloan Management Review, Winter, 94-104.

Bayol, M. P., De la Foye, A., Tellier, C., \& Tenenhaus, M. (2001). Use of PLS Path Modeling to Estimate the European Consumer Satisfaction Index (ECSI) Model. Statistica Applicata - Italian Journal of Applied Statistics, 12, 361-375.

Beatty, S. E., Mayer, M., Coleman, J. E., Reynolds, K. E., \& Lee, J. (1996). Customer-sales associate retail relationships. Journal of Retailing, 72(3), 223-47.

Bitner, M. J., \& Zeithaml, V. A. (2003). Service Marketing (3rd ed.). New Delhi: Tata McGraw Hill.

Bollen, K. A. (1990). Overall fit in covariance structure models: two types of sample size effects. Psychological Bulletin, 107, 256-259. http://dx.doi.org/10.1037/0033-2909.107.2.256

Bollen, K. A., \& Long, J. S. (1993). Testing Structural Equation Models. CA: Sage. 
Bolton, R. N., \& Drew, J. H. (1991). A multistage model of customers' assessments of service quality and value. Journal of Consumer Research, 17(January), 375-384. http://dx.doi.org/10.1086/208564

Bontis, N., Booker, L. D., \& Serenko, A. (2007). The mediating effect of organizational reputation on customer loyalty and service recommendation in the banking industry. Management Decision, 45(9), 1426-1445.

Boselie, P., Hesselink, M., \& Wiele, T. V. (2002). Empirical evidence for the relationship between customer satisfaction and business performance. Managing Service Quality, 12(3), 184-193. http://dx.doi.org/10.1108/09604520210429259

Boulding, W., Kalra, A., Staelin, R., \& Zeithaml, V. A. (1993). A dynamic process model of service quality: from expectations to behavioral intentions. Journal of Marketing Research, 30(February), 7-27. http://dx.doi.org/10.2307/3172510

Brady, M. K., \& Cronin, J. J. (2001). Some new thoughts on conceptualizing perceived service quality: A hierarchical approach. Journal of Marketing, 65(3), 34-49. http://dx.doi.org/ 10.1509/jmkg.65.3.34.18334

Burnham, T. A., Frels, J. K., \& Mahajan, V. (2003). Consumer switching costs: a typology, antecedents and consequences. Journal of the Academy of Marketing Science, 31(2), 109-126. http://dx.doi.org/10.1177/0092070302250897

Buzzell, R. D., \& Gale, B. T. (1987). The PIMS Principles: Linking Strategy to Performance. New York: The Free Press.

Byrne, B. M. (2001). Structural Equation Modeling with AMOS, Basic Concepts, Applications, and Programming. Hillsdale, New Jersey: Lawrence Erlbaum Associates.

Carman, J. M. (1990). Consumer perceptions of service quality: an assessment of SERVQUAL Dimensions. Journal of Retailing, 66(1), 33-55.

Chiou, J. S. (2004). The antecedents of consumer's loyalty towards Internet service providers. Information \& Management, 41(6), 685-695.

Corbitt, B. J., Thanasankit, T., \& Yi, H. (2003). Trust and e-commerce: a study of consumer perceptions. Electronic Commerce Research \& Applications, 2(3), 203-215.

Coulter, K. S., \& Coulter, R. A. (2003). The effects of industry knowledge on the development of trust in service relationships. International Journal of Research in Marketing, 20, 31-43.

Cronin, J. J., \& Taylor, S. A. (1992). Measuring service quality: a reexamination and Extension. Journal of Marketing, 56(July), 55-68. http://dx.doi.org/10.2307/1252296

Cronin, J. J., Brady, M. K., \& Hult, G. T. M. (2000). Assessing the Effects of Quality, Value and Customer Satisfaction on Consumer Behavioral Intentions in Service Environments. Journal of Retailing, 76(2), 193-218. http://dx.doi.org/10.1016/S0022-4359(00)00028-2

Dabholkar, P. A., Shepherd, D. C., \& Thorpe, D. I. (2000). A comprehensive framework for service quality: an investigation of critical conceptual and measurement issues through a longitudinal study. Journal of Retailing, 76(2), 139-73.

Dick, A., \& Basu, K. (1994). Customer loyalty: toward an integrated conceptual framework. Journal of the Academy of Marketing Science, 22(2), 99-113. http://dx.doi.org/10.1177/0092070394222001

Doney, P. M., \& Cannon, J. P. (1997). An examination of the nature of trust in buyer-seller relationships. Journal of Marketing, 61(April), 35-51.

Dotchin, J. A., \& Oakland, J. S. (1994). Total Quality Management in Services Part 2: Service quality. International Journal of Quality \& Reliability Management, 11(3), 27-42. http://dx.doi.org/10.1108/02656719410056459

Fink, C., Matto, A., \& Rathindran, R. (2003). An assessment of Telecommunications Reform in Developing Countries. Information Economics and Policy, 15, 443- 466.

Fornell, C. (1992). A national customer satisfaction barometer: the Swedish experience. Journal of Marketing, 56(January), 6-21. http://dx.doi.org/10.2307/1252129

Fornell, C., \& Larcker, D. F. (1981). Evaluating structural equation models with unobservable variables and measurement error. Journal of Marketing Research, 18(3), 39-50. http://dx.doi.org/10.2307/3151312

Foster, B. D., \& Cadogen, J. W. (2000). Relationship selling and customer loyalty: an empirical investigation. 
Marketing Intelligence and Planning, 18, 85-99.

Garson, G. D. (2012). Testing Statistical Assumption, Blue Book series (pp. 17-18). Statistical Associates Publishing. Retrieved December 15, 2012, from http://www.statisticalassociates.com/assumptions.pdf

Gerbing, D. W., \& Anderson, J. C. (1993). Monte Carlo evaluation of goodness-of-fit indices for structural equations models. In K. A. Bollen \& J. S. Long (Eds.), Testing structural equation models (pp. 40-65). Newbury Park, CA: Sage.

Graack, C. (1996). Telecom operators in the European Union: Internationalized strategies and network alliances. Telecommunications Policy, 20(5), 341-355.

Gremler, D. D., \& Brown, S. W. (1996). Service Loyalty: Its Nature, Importance, and Implications: in Advancing Service Quality: A Global Perspective. International Service Quality Association, 171-180.

Grönroos, C. (1984). A service quality model and its marketing implications. European Journal of Marketing, 18(4), 36-44. http://dx.doi.org/10.1108/EUM0000000004784

Grönroos, C. (1990). Service Management and Marketing. Lexington, MA: Lexington Books.

Hadjikhani, A., \& Thilenius, P. (2005). The impact of horizontal and vertical connections on relationships: Commitment and Trust. The Journal of Business \& Industrial Marketing, 20(2/3), 136-148.

Hair, J. F., Anderson, R. E., Tatham, R. L., \& Black, W. C. (2006). Multivariate Data Analysis (6th ed.). Pearson Education.

Hart, C. W., \& Johnson, M. D. (1999). Growing the trust relationship. Marketing Management, 14(Spring), 8-19.

Herbig, P., \& Milewicz, J (1993). The relationship of reputation and credibility to brand success. Journal of Consumer Marketing, 10(1), 5-10.

Hsieh, Y. C., \& Hiang, S. T. (2004). A study of the impacts of service quality on relationship quality in search-experience-credence services. Total Quality Management, 15(1), 43-58.

Hyde, A., \& Gosschalk, B. (2005). The business world will never be the same: the contribution of research to corporate governance post-Enron. International Journal of Market Research, 47(1), 29-44.

Jackson, B. B. (1985). Winning and Keeping Industrial Customers. MA: Lexington Books.

James, L. R., Mulaik, S. A., \& Brett, J. M. (1982). Causal analysis: Assumptions, models, and data. Beverly Hills, CA: Sage.

Jarvenpaa, S. L., Tractinsky, N., \& Vitale, M. (2000). Consumer Trust in an Internet Store. Information Technology and Management, 1(1-2), 45-71. http://dx.doi.org/10.1023/A:1019104520776

Jones, M. A., Beatty, S. E., \& Mothersbaugh, D. V. (2002). Why customers stay: measuring the underlying dimensions of services switching costs and managing their differential strategic outcomes. Journal of Business Research, 55, 441-50.

Joreskog, K. G., \& Sorbom, D. (1993). LISREL 8: structural Equation Modeling with the SIMPLIS Command Language: Scientific International Software. Chicago, IL.

Kennedy, S. H. (1977). Nurturing corporate image. European Journal of Marketing, 11(3), 120-64.

Kim, M., Kliger, D., \& Vale, B. (2003). Estimating switching costs: the case of banking. Journal of Financial Intermediation, 12(1), 25-56.

Kline, R. B. (1998). Principles and Practice of Structural Equation Modeling. New York: The Guilford Press.

Kline, R. B. (2005). Principles and Practice of Structural Equation Modeling (2nd ed.). New York: The Guilford Press.

Kotler, P., \& Singh, R. (1981). Marketing warfare in the 1980s. Journal of Business Strategy, 3, 30-4.

Kristensen, K., Martensen, A., \& Grønholdt, L. (2000). Customer satisfaction measurement at Post Denmark: results of application of the European Customer Satisfaction Index methodology. Total Quality Management, 11(7), 1007-15.

Lai, F., Griffin, M., \& Babin, B. J. (2009). How quality, value, image, and satisfaction create loyalty at a Chinese telecom. Journal of Business Research, 62(10), 980-986. 
Lam, S. Y., Shankar, V., Erramilli, M. K., \& Murthy, B. (2004). Customer value, satisfaction, loyalty, and switching costs: an illustration from a business-to-business service context. Journal of the Academy of Marketing Science, 32, 293-311.

Lau, G., \& Lee, S. (1999). Consumers' trust in a brand and link to brand loyalty. Journal of Market Focused Management, 4, 341-70.

Lee, J., Lee, J., \& Feick, L. (2001). The impact of switching costs on the customer satisfaction-loyalty link: Mobile phone service in France. Journal of Services Marketing, 15, 35-48. http://dx.doi.org/10.1108/08876040110381463

Lewis, B. R. (1993). Service quality: recent developments in financial services. International Journal of Bank Marketing, 2(6), 19-26.

Liang, C. J., \& Wang, W. H. (2008). Do Loyal and More Involved Customers Reciprocate Retailer's Relationship Efforts? Journal of Services Research, 8(1), 63-90.

Lin, L. Y., \& Lu, C. Y. (2010). The influence of corporate image, relationship marketing, and trust on purchase intention: the moderating effects of word-of-mouth. Tourism Review, 65(3), 16-34.

MacInnis, D. J., \& Price, L. L. (1987). The role of Imagery in Information Processing: Review and Extensions. Journal of Consumer Research, 13, 473-491.

Moorman, C., Deshpande, R., \& Zaltman, G. (1993). Factors affecting trust in market research relationships. Journal of Marketing, 57(January), 81-101.

Morgan, R. M., \& Hunt, S. D. (1994). The commitment-trust theory of relationship Marketing. Journal of Marketing, 58(July), 20-38. http://dx.doi.org/10.2307/1252308

Narayandas, N. (1996). The link between customer satisfaction and customer loyalty: an empirical investigation. Working Paper, No. 97-017. Harvard Business School, Boston, MA.

Nguyen, N., \& LeBlanc, G. (2001). Corporate image and corporate reputation in customers' retentions decisions in services. Journal of Retailing and Consumer Services, 8, 227-36. http://dx.doi.org/10.1016/S0969-6989(00)00029-1

Nunnally, J. C. (1978). Psychometric theory (2nd ed.). NY: McGraw Hill.

Oliver, R. L. (1997). Satisfaction: A Behavioral Perspective on the Consumer. NY: McGraw-Hill.

Orth, U. R., \& Green, M. T. (2009). Consumer loyalty to family versus non-family business: The roles of store image, trust and satisfaction. Journal of Retailing and Consumer Services, 16(4), 248-259. http://dx.doi.org/10.1016/j.jretconser.2008.12.002

Parasuraman, A., Zeithaml, V. A., \& Berry, L. L. (1985). A conceptual model of service quality and its implications for future research. Journal of Marketing, 49(Fall), 41-50. http://dx.doi.org/10.2307/1251430

Parasuraman, A., Zeithaml, V. A., \& Berry, L. L. (1988). SERVQUAL: a multiple-item scale for measuring consumer perceptions of service quality. Journal of Retailing, 64(Spring), 12-40.

Pearson, N. (1996). Building brands directly: creating business value from customer Relationships. Macmillan Business, 20(6), 68-82.

Ping, R. A. (1993). The effects of satisfaction and structural constraints on retailer exiting, voice, loyalty, opportunism, and neglect. Journal of Retailing, 69(3), 321-349.

Poon, M. L. (2004). Effects of performance appraisal politics on job satisfaction and turnover Intention. Personnel Review, 33(3), 322-334.

Porter, M. (1998). Competitive Strategy: Techniques for Analyzing Industries and Competitors. New York: The Free Press.

Prus, A., \& Brandt, D. R. (1995). Understanding Your Customers. American Demographics, 11.

Rust, R. T., \& Zahorik, A. J. (1993). Customer satisfaction, customer retention, and market share. Journal of Retailing, 69, 193-215. http://dx.doi.org/10.1016/0022-4359(93)90003-2

Sharma, N., \& Patterson, G. P. (1999). The impact of communication effectiveness and service quality on relationship commitment in consumer, professional services. The Journal of Services Marketing, 13(2), 151-170. http://dx.doi.org/10.1108/08876049910266059 
Sharp, B., \& Sharp, A. (1997). Loyalty programs and their impact on repeat-purchase loyalty patterns. International Journal of Research in Marketing, 14(5), 473-486. http://dx.doi.org/10.1016/S0167-8116(97)00022-0

Singh, J., \& Sirdeshmukh, D. (2000). Agency and trust mechanisms in customer satisfaction and loyalty judgments. Journal of the Academy of Marketing Science, 28(1), 150-67. http://dx.doi.org/10.1177/0092070300281014

Sirdeshmukh, D., Singh, J., \& Sabol, B. (2002). Consumer trust, value and loyalty in relational exchanges. Journal of Marketing, 66(1), 15-37. http://dx.doi.org/ 10.1509/jmkg.66.1.15.18449

Spreng, R. A., \& Mackoy, R. D. (1996). An empirical examination of a model of perceived service quality and satisfaction. Journal of Retailing, 72(2), 201-14. http://dx.doi.org/10.1016/S0022-4359(96)90014-7

Straub, D. W. (1989). Validating instruments in MIS research. MIS Quarterly, 13(2), 147-70.

Sureshchandar, G. S., Rajendran, C., \& Anantharaman, R. N. (2002). The relationship between service quality and customer satisfaction - a factor specific approach. Journal of Service Marketing, 16(4), 363-379. http://dx.doi.org/10.1108/08876040210433248

Taylor, S. A. (1995). The effects of filled waiting time and service provider control over the delay on evaluations of service. Journal of the Academy of Marketing Science, 23(1), 38-48.

Turel, O., \& Serenko, A. (2006). Satisfaction with mobile services in Canada: An empirical investigation. Telecommunications Policy, 30(5/6), 314-331.

Vesel, P., \& Zabkar, V. (2009). Managing customer loyalty through the mediating role of satisfaction in the DIY retail loyalty program. Journal of retailing and customer services, 16, 396-406.

Walczuch, R., Seelen, J., \& Lundgren, H. (2001). Psychological determinants for consumer trust in e-retailing. Proceedings of the 8th Research Symposium on Emerging Electronic Markets. Retrieved March 2, 2009, from http://www-i5.informatik.rwth-achen.de/conf/rseem2001/papers/walczuch.pdf

Wang, Y., Lo, H. P., \& Yang, Y. H. (2004). An integrated framework for service quality, customer value, satisfaction: evidence from China's telecommunication industry. Information Systems Frontiers, 6(4), $325-40$.

Yen, H., \& Gwinner, K. (2003). Internet retail customer loyalty: the mediating role of relational benefits. International Journal of Service Industry Management, 14(5), 483-500. http://dx.doi.org/10.1108/09564230310500183

Yuille, J. C., \& Catchpole, M. J. (1977). The role of imagery in models of cognition. Journal of Mental Imagery, $1,171-80$.

Zeithaml, V. A., Berry, L. L., \& Parasuraman, A. (1996). The behavioral consequences of service quality. Journal of Marketing, 60(1), 31-46. http://dx.doi.org/10.2307/1251929

Zeithaml, V. A., Parasuraman, A., \& Berry, L. L. (1990). Delivering Quality Service: Balancing Customer Perceptions and Expectations. New York: The Free Press.

\section{Copyrights}

Copyright for this article is retained by the author(s), with first publication rights granted to the journal.

This is an open-access article distributed under the terms and conditions of the Creative Commons Attribution license (http://creativecommons.org/licenses/by/3.0/). 